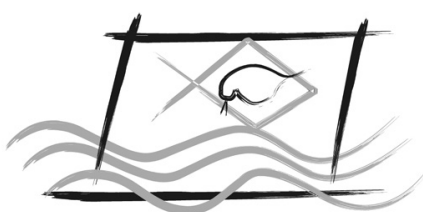

ECOTOX - BRASIL

\title{
Evaluation of resveratrol toxicity in the embryolarval stage of Danio rerio fish
}

\author{
Cavalcante, A.K. ${ }^{1}$; Lopes-Ferreira, M. ${ }^{2}$; Rogero, S.O. ${ }^{1}$ \& Rogero, J.R. ${ }^{1}$ \\ 1- Laboratório de Ecotoxicologia - Centro de Química e Meio Ambiente - Instituto de Pesquisas Energéticas e Nucleares (IPEN) - \\ Comissão Nacional de Energia Nuclear- IPEN/CNEN-SP, São Paulo, Brasil. \\ 2- Laboratório Especial de Toxinologia Aplicada (LETA) - Instituto Butantan, São Paulo, Brasil.
}

(Received August 03, 2017; Accept November 16, 2017)

\begin{abstract}
Human beings concern about healthy life has driven researchers to study new compounds capable of reaching that desire. Resveratrol (3,4 ', 5-trihydroxystilbene) a phenolic compound, is one of these substances which presents a variety of pharmacological actions, as antioxidant potential, anti-inflammatory capacity, protection against heart and cancer diseases. Despite the resveratrol health benefits studies, there is a little evidence of its toxicity in the literature in aquatic organisms, and especially the data on the concentration of resveratrol in the environment, making the present study fundamental for information about resveratrol ecotoxicity in the aquatic system. The aim of this study was to evaluate the toxicity of resveratrol in embryos and larvae of Danio rerio (zebrafish). The in vitro cytotoxicity and ecotoxicity assays were performed. The $\mathrm{IC}_{50}$ obtained in the NCTC-L929 cell line cytotoxicity assay was $38.5 \mathrm{mg} \mathrm{L}^{-1}$. The $\mathrm{LC}_{50}(96 \mathrm{~h})$ obtained in fish embryo toxicity test was $75.3 \mathrm{mg} \mathrm{L}^{-1}$ and the mean value of resveratrol $\mathrm{LC}_{50}(168 \mathrm{~h})$ obtained in the short-term chronic ecotoxicity assays performed with zebrafish larvae was $51.4 \mathrm{mg} \mathrm{L}^{-1}$. This work provided data on the toxicity of resveratrol in the embryonic stage of fish of the species Danio rerio and the toxic effects are dependent on its concentration.
\end{abstract}

Key-words: Danio rerio; Ecotoxicology; Fish embryo toxicity test; Resveratrol; Zebrafish.

\section{INTRODUCTION}

The search for human beings healthy life has driven researchs for new substances capable of meeting that purpose. Among these substances we find the phenolic compound resveratrol (3, 4 ', 5-trihydroxystilbene). The phenolic compound resveratrol is a phytoalexin which belongs to the stilbene family (Jeandet et al., 2002). Phytoalexins are antimicrobial compounds produced by several plant species under stress conditions, which may be caused by biotic or abiotic factors, giving plants a protection against different diseases (VanEtten et al., 1994).

Resveratrol was identified in 72 plant species, such as blackberry, peanut, eucalyptus and grape. The species Vitis vinifera and Vitis labrusca, present the greatest resveratrol synthesis capacity, and the grape and its industrialized products are important sources of this compound (Vuong et al., 2014).

In grapes, resveratrol is produced in fruit peels at various concentrations, and in wine, the concentration of the compound depends on several factors, such as geographical origin, wine type, oenological practices, climatic conditions and degree of infection of the plant by fungi (Fernández-Mar et al., 2012).

Studies have shown that resveratrol has a wide variety of biological activities, such as antioxidant activity; anti-inflammatory; antimicrobial; anticancer; neuroprotective; cardioprotective; reduction of obesity; inhibition of platelet aggregation and estrogenic activity (Gülçin, 2010; Leonard et al., 2003).

Although it is established that resveratrol exerts beneficial effects on humans and other living beings, its mechanism of action is not well understood. According to Mukherjee 
et al. (2010), in low doses resveratrol has anti-apoptotic and cardioprotective function. However, in high doses it presents pro-apoptotic actions, preventing tumor development, but on the other hand, can also cause structural chromosomal aberrations and increase the incidence of myocardial infarction. The functions of the compound tend to indicate that its effects are dose-dependent

It is known that resveratrol is absorbed by the intestine and eliminated rapidly, and the excretion with its metabolites occur with the help of bile and urine (Leonard et al., 2003), however, there is no literature data on the concentration of the compound in the environment. Despite the numerous studies on the health benefits of resveratrol, there is little data in the literature on its toxicity in aquatic organisms, making the present study fundamental for the contribution of new information on the ecotoxicity of resveratrol in the aquatic environment.

Toxicity tests are capable of evaluating environmental impacts, since the knowledge of the contaminants toxicity makes it possible to establish the permissible limits of several chemical substances for the protection of aquatic life (Zagatto $\&$ Bertoletti, 2006).

The species Danio rerio (zebrafish) is an important animal model used in the areas of developmental biology, genetics and biomedicine (Grunwald \& Eisen, 2002) and it is used in ecotoxicological trials through Brazilian and International standards. As zebrafish presents $70 \%$ genetic similarity with humans, as well as physiological and anatomical similarities, this model can be used to predict toxicity effects in humans (Hill et al., 2005; Bar-llan et al., 2009). In addition to high reproductive rate and rapid embryonic development (out of the maternal body), the species shows great sensitivity when exposed to chemicals, being able to quickly absorb the compounds that are directly added to the water and accumulate them in various tissues. The organism is easy to obtain, manage and it is low cost (Zagatto \& Bertoletti, 2006).

The aim of this study was to evaluate the toxicity of resveratrol in embryos and larvae of Danio rerio (zebrafish). For this purpose the in vitro cytotoxicity and ecotoxicity assays were performed.

\section{MATERIAL AND METHODS}

\section{Chemical}

Resveratrol (3, 4', 5- trihydroxy-trans-stilbene) was purchased from Sunrise Chemical Ltd. - China, imported and marketed by Pharma Nostra, Campinas - SP. Resveratrol was extracted from the root of the plant Polygonum cuspidatum Sieb, and the companies attest the compound as the standard resveratrol trans isomer form with $99.4 \%$ purity. All the other chemical compounds used were analytical grade.

\section{Fish Husbandry}

Adults zebrafish (Danio rerio) are kept in the Special Laboratory of Applied Toxinology (LETA), of the Butantan
Institute, in aquariums with reconstituted deionized water, conductivity of $500 \mu \mathrm{S}, \mathrm{pH} 7.0$ to 7.5 , temperature of 28 $\pm 1{ }^{\circ} \mathrm{C}$, and photoperiod cycle of $14 \mathrm{~h}$ light $/ 10 \mathrm{~h}$ dark and fed three times daily with commercially available fish food and Artemia.

Danio rerio eggs were collected immediately after natural mating and transported to the Ecotoxicology Laboratory of the Chemistry and Environment Center (CQMA) of the Energy and Nuclear Research Institute (IPEN / CNEN-SP). The fertilized eggs were selected under a stereomicroscope. Fertilized eggs were used in the fish embryo toxicity test. To obtain the larvae, the eggs were kept in an incubator at $28 \pm$ $1{ }^{\circ} \mathrm{C}$, with photoperiod cycle of $14 \mathrm{~h}$ of light/ $10 \mathrm{~h}$ dark and 48 $\mathrm{h}$ post fertilization (hpf), hatched larvae were used in shortterm chronic ecotoxicity assays.

\section{In vitro cytotoxicity assay}

In vitro cytotoxicity assay was performed to determine the half maximal inhibitory concentration $\left(\mathrm{IC}_{50}\right.$ - extract concentration which induces $50 \%$ lysis or cell death) of resveratrol following International Standard ISO 10993-5. This assay was performed by the neutral red uptake method. Diluted solutions of resveratrol $(6.2 \% ; 12.5 \% ; 25 \% ; 50 \%$ and $100 \%$ ) were placed in contact with NCTC-L929 (CCIAL 020), mouse connective tissue cells, distributed in 96 well microplates. The microplates were supplied by the Nucleus of Cell Cultures of the Adolfo Lutz Institute. In the assay, in addition to cell control, a negative and a positive control were tested. Cell viability was verified by the incorporation of neutral red by the living and intact cells. The optical density reading of the final microplate solution was performed in a spectrophotometer, ELISA reader-SUNRISE, at $540 \mathrm{~nm}$, after cell lysis. The percentage of cell viability was calculated in relation to the control cells and projected on a graphic, as a function of the concentration of resveratrol obtaining a curve that indicated the $\mathrm{IC}_{50}$.

\section{Fish embryo toxicity (FET) test}

The assay was based on the OECD 236 (Guideline on Fish Embryo Toxicity Test - FET) (2013), to determine the resveratrol lethal concentration $\left(\mathrm{LC}_{50}\right)$. Based on the half maximal inhibitory concentration of resveratrol $\left(\mathrm{IC}_{50}\right)$ obtained in the above test, a preliminary test with zebrafish embryos was performed, the last concentration of resveratrol being 100 $\mathrm{mg} \mathrm{L}^{-1}$. From this test, the definitive test was performed.

Sixty eggs per treatment were used and distributed in three 24-well microplates (replicates). Eggs were placed in each well individually with $2 \mathrm{~mL}$ of test solution. The treatments used were: control (reconstituted deionized water), solvent control dimethyl sulfoxide (DMSO) and resveratrol test solution at nominal concentrations of $0.5 ; 1.1 ; 2.3 ; 4.8 ; 10.3$; 22; 46.9 and $100 \mathrm{mg} \mathrm{L}^{-1}$. The microplates were maintained in an incubator, in the temperature range of $26 \pm 1{ }^{\circ} \mathrm{C}$ and photoperiod cycle of $14 \mathrm{~h}$ light / $10 \mathrm{~h}$ dark, during $96 \mathrm{~h}$. 
Test solutions were prepared at the time of the assay by stock solution dilution in reconstituted deionized water. Resveratrol stock solution was prepared by dissolving resveratrol on DMSO and deionized water. The test solutions were renewed $48 \mathrm{~h}$ after the start of the assay. Solvent control containneds $15 \mu \mathrm{L}$ of DMSO, the highest concentration of solvent used in the test.

The organisms were observed by the inverted microscope every $24 \mathrm{~h}$. In the embryonic phase the following parameters were observed: coagulation of fertilized eggs, heartbeats, pigmentation of the eyes and body, formation of somites, tail detachment, hatching and lethality. After hatching, the parameters evaluated in the larvae were: heartbeats, oedemas, spine deformity and lethality. At the end of the test, $\mathrm{LC}_{50}$ was determined on the basis of lethality results of organisms.

\section{Short-term chronic ecotoxicity test with fish larvae}

The test was performed with adaptations of the norm ABNT NBR 15499 (Short-term chronic toxicity - Fish test method) (2007), to determine the resveratrol lethal concentration $\left(\mathrm{LC}_{50}\right)$ on zebrafish. The larval less than $24 \mathrm{~h}$ after hatching were exposed to different concentrations of resveratrol for a period of $168 \mathrm{~h}$ and the effect evaluation was lethality. A preliminary test was performed to determine the concentration range to be used. In this preliminary study, concentrations of resveratrol were: $2.3 ; 4.8 ; 10.3 ; 22 ; 46.9$ and $100 \mathrm{mg} \mathrm{L}^{-1}$, in addition to the control with reconstituted deionized water and solvent control (DMSO). From this test, definitive assay was performed in triplicate $(\mathrm{n}=3)$.

The organisms were exposed to the following concentrations of resveratrol: $3.1 ; 6.2 ; 12.5 ; 25 ; 50$ and $100 \mathrm{mg} \mathrm{L}^{-1}$, which were determined by dilution factor 2 , as requested by ABNT NBR 15499 (2007). For each resveratrol concentration was used four replicates containing 10 larvae in $250 \mathrm{~mL}$ of test solution, prepared by dilution of stock solution (resveratrol on DMSO and deionized water) in reconstituted deionized water. The same proceeding was used for control, utilizing reconstituted deionized water as test solution. In relation to the solvent control, DMSO was used in concentrations of: 2,4 and $8 \mathrm{mg} \mathrm{L}^{-1}$. The organisms were maintained without feeding, in an incubator at a temperature of $25 \pm 2^{\circ} \mathrm{C}$ and photoperiod cycle of $14 \mathrm{~h}$ light $/ 10 \mathrm{~h}$ dark.

The test solutions were renewed daily, therefore, they were produced daily, as well as the stock solution. The larvae were observed every $24 \mathrm{~h}$ during the test, and the lethality was evaluated by the absence of the heartbeats, measured for 2 min using a binocular loupe with a minimum magnification of $80 \mathrm{x}$. At the end of each test, $\mathrm{LC}_{50}$ was determined based on the lethality results of the organisms.

\section{Statistical analysis}

With the percentage of lethality of the organisms, the estimation of concentrations that had effect on $50 \%$ of the exposed organisms was calculated using the non-parametric statistical method Trimmed Spearman-Karber (Hamilton et al., 1977). The hatch rates and deformities observed in the organisms during the test were evaluated by Student's $t$-test, to verify if the resveratrol showed statistically significant differences on the organisms in comparison with the control, with significance level of $\mathrm{p}<0.05$.

\section{RESULTS AND DISCUSSION}

Information about toxicity data of resveratrol in Danio rerio was not available in the literature. Because of that, the discussion was conducted with toxicity information of drugs, metals and insecticides in zebrafish.

\section{In vitro cytotoxicity assay}

The results of resveratrol cytotoxicity are presented in the Figure 1. The controls are used to verify the effectiveness of the assay. The sample whose cell viability curve projects above the $\mathrm{IC}_{50}$ line is considered non-cytotoxic, as observed in the negative control. However, the sample presenting a cell viability curve below or crossing the $\mathrm{IC}_{50}$ line is considered to be cytotoxic, as observed in the positive control. The $\mathrm{IC}_{50}$ is estimated at the intersection between the cell viability curve and the line of $50 \%$ viability in the graph. Resveratrol had $\mathrm{IC}_{50}$ of about $77 \%$, which corresponds to the concentration of 38.5 $\mathrm{mg} \mathrm{L}^{-1}$, and the positive control $\mathrm{IC}_{50}$ was $68 \%\left(34 \mathrm{mg} \mathrm{L}^{-1}\right)$, being $100 \%$ corresponding to the concentration of $50 \mathrm{mg} \mathrm{L}^{-1}$, the highest concentration used in the test.

\section{Fish embryo toxicity (FET) test}

The fertilized zebrafish eggs were exposed to eight concentrations of resveratrol for $96 \mathrm{~h}$. After $48 \mathrm{~h}$, the control groups (95\%) had a normal embryonic development as described by Kimmel et al. (1995). However, in the concentration of $100 \mathrm{mg} \mathrm{L}^{-1}$ of resveratrol, observed in $67 \%$ of the embryos the lack of pigmentation of the eyes and body

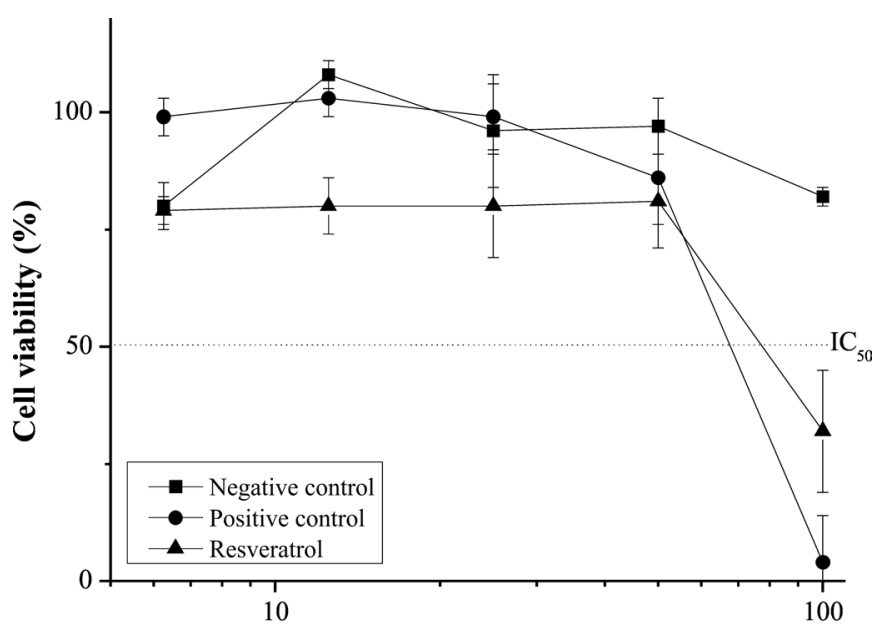

Extract concentration (\%)

Figure 1: Cell viability curves in the cytotoxicity assay of resveratrol by the Neutral Red Uptake methodology. 
(Figure 2) and slow heart rate, representing a statistically significant difference in relation to controls.

Embryos mortality in control was below $10 \%$ as required for test validity. Figure 3 shows the lethality curve (\%) of the zebrafish in the fish embryo toxicity test of resveratrol (mg $\left.\mathrm{L}^{-1}\right)$. It was observed lethality after $46.9 \mathrm{mg} \mathrm{L}^{-1}$ resveratrol concentration and in the lower concentrations the lethality was in the normal range, less than $10 \%$.

The $\mathrm{LC}_{50}$ (96h) of resveratrol to zebrafish embryos was 75.3 $\mathrm{mg} \mathrm{L}^{-1}$. In study conducted by Damasceno et al. (2016), the $\mathrm{EC}_{50}$ that is the effective concentration causing immobility in 50\% of exposed organisms of resveratrol in Daphnia similis was 3.6 $\mathrm{mg} \mathrm{L}^{-1}$, what shows that Daphnia similis had a more sensitive response than Danio rerio's embryos to the resveratrol.

Hatching has been widely used as a parameter in the embryological stage of fish. The percentage of zebrafish hatch observed during the fish embryo toxicity test is presented in the table 1 . The test conducted in order to evalute the DMSO toxicity in concentrations used on fish embryo toxicity test was not toxic to zebrafish embryos.

The embryos exposure to resveratrol from 0.5 to 2.3 mg $\mathrm{L}^{-1}$ did not show statistically difference in hatching rate in comparison to the control, in the $48 \mathrm{~h}$ period. In the

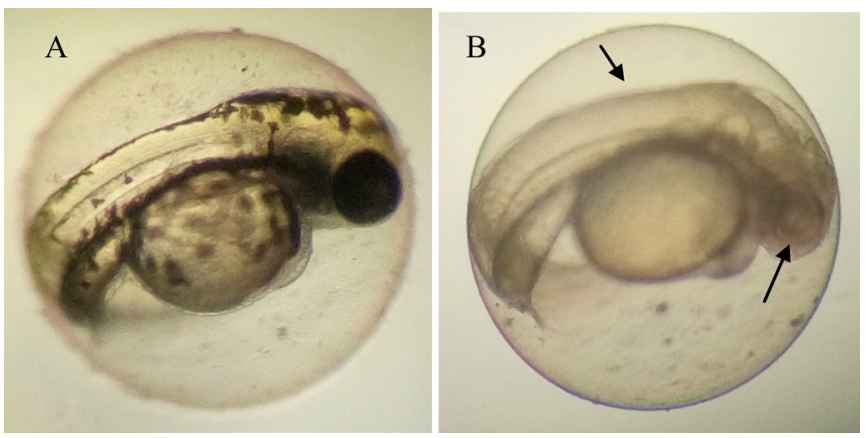

Figure 2: (A) Control with pigmentation of the eyes and body; (B) Embryo without pigmentation of the eyes and body (black arrows) after $48 \mathrm{~h}$ of exposition in resveratrol $100 \mathrm{mg} \mathrm{L}-1$.

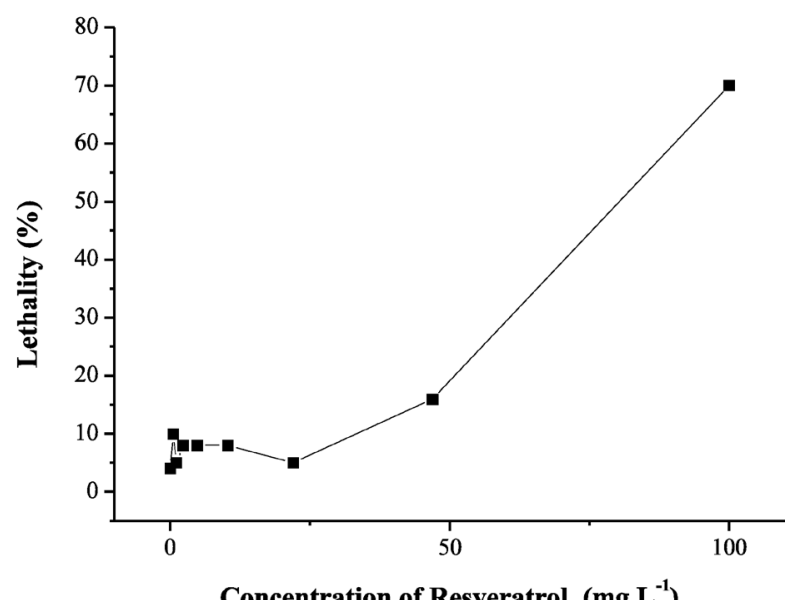

Figure 3: Lethality curve of zebrafish in the embryolarval stage, on relation to resveratrol concentrations after $96 \mathrm{~h}$ of exposure. " $0 *$ " refers to solvent control.
Table 1- Hatching rate of zebrafish larvae at 48, 72 and $96 \mathrm{~h}$.

\begin{tabular}{lccc}
\hline \multirow{2}{*}{$\begin{array}{l}\text { Resveratrol } \\
\left(\mathbf{m g ~ L ~}^{-1}\right)\end{array}$} & $\mathbf{4 8 ~ h}$ & $\mathbf{7 2} \mathbf{~ h}$ & $\mathbf{9 6} \mathbf{~ h}$ \\
\cline { 2 - 4 } & & 100 & 100 \\
\hline Solvent Control & 37 & 97 & 100 \\
0 & 32 & 98 & 100 \\
0.5 & 63 & 100 & 100 \\
1.1 & 73 & 100 & 100 \\
2.3 & 50 & 100 & 100 \\
4.8 & 35 & 98 & 100 \\
10.3 & 45 & 98 & 100 \\
22 & 28 & 84 & 97 \\
46.9 & 18 & 36 & 76 \\
100 & $7^{*}$ & & \\
\hline
\end{tabular}

* Mean significantly different from control (Student's t-test, $\mathrm{p}<0.05$ )

concentrations of $100 \mathrm{mg} \mathrm{L}^{-1}$ of resveratrol a statistically difference in hatching delay was observed in comparison to the control, in $48 \mathrm{~h}$ period.

It is known that physical and chemical signals detected by the embryo activate the production of the hatchery-related enzyme (chorionase), which degrades the inner layer of the chorion and allows movements that provide the hatching event (Fuiman, 2002). Different toxic mechanisms may justify delayed hatching or failure, such as induction of abnormal function of the chorionase enzyme and / or the inability of emerging larvae to break eggshells (Hallare et al., 2005; Jezierska et al., 2009).

The organisms hatching process may be dependent on the concentration of resveratrol. The results suggests that resveratrol is able to induce or inhibit the activity of the enzyme chorionase. According to Jezierska et al. (2009) some metals may inhibit or accelerate the hatching process of fish. Dave \& Xiu (1991) reported the delay in hatching of Danio rerio embryos exposed to copper and nickel. The authors mentioned above suggest that copper may inactivate the chorionase enzyme and cause osmotic disorders that can also affect the muscle movements needed to break the egg. The delay of the hatching of Danio rerio was also verified in the study of Bai et al. (2010); Muller et al. (2015) and Oliveira et al. (2009). However, premature hatching was observed in the studies of Jesus et al. (2013) and Oliveira et al. (2013), where there was an increase in the hatch rate of Danio rerio exposed to the antiseptic chlorhexidine and the antibiotic amoxicillin.

Deformities and lethality were observed in the organisms exposed to 46.9 and $100 \mathrm{mg} \mathrm{L}^{-1}$ during the assay. The observed deformities were: pericardial oedema, oedema of the yolk sac and spine deformity. All deformations were statistically different from the controls.

\section{Short-term chronic ecotoxicity test with fish larvae}

Danio rerio larvae were exposed for $168 \mathrm{~h}$ to several concentrations of resveratrol. The larvae mortality in control and in solvent control was below $20 \%$, as required for test 
validity. In the Figure 4 is shown the mean and standard deviation of the lethality rate (\%) according to resveratrol concentrations $\left(\mathrm{mg} \mathrm{L}^{-1}\right)$. It is observed that the rate of lethality increases as the concentration of resveratrol increases.

The table 2 shows the results of short-term chronic ecotoxicity assay of resveratrol on zebrafish larvae.

The mean value of resveratrol $\mathrm{LC}_{50}(168 \mathrm{~h})$ obtained in the short-term chronic ecotoxicity assay performed with zebrafish larvae was $51.4 \mathrm{mg} \mathrm{L}^{-1}$. The result is lower than the $\mathrm{LC}_{50}$ (96h) $\left(75.3 \mathrm{mg} \mathrm{L}^{-1}\right)$ obtained in the fish embryo toxicity test. The results show that the larvae stage is considerable more sensitive than the embryonic stage. The difference in the sensitivity of the organisms can be explained by the fact that the embryos when exposed to resveratrol in FET test has the chorion protection, which provided a barrier and reduce the substances exposition.

However, it was verified in FET test a high lethality of organisms $(70 \%)$ at $100 \mathrm{mg} \mathrm{L}^{-1}$ of resveratrol concentration, and in the study performed by Vallverdú-Queralt et al. (2015), resveratrol was found in embryos of Danio rerio when exposed to the red wine extract, so it can be inferred that the resveratrol crossed the egg chorion and caused effects on the embryos. The recently hatched larvae have no structure to prevent or reduce the exposure to resveratrol in the short-term chronic ecotoxicity test.

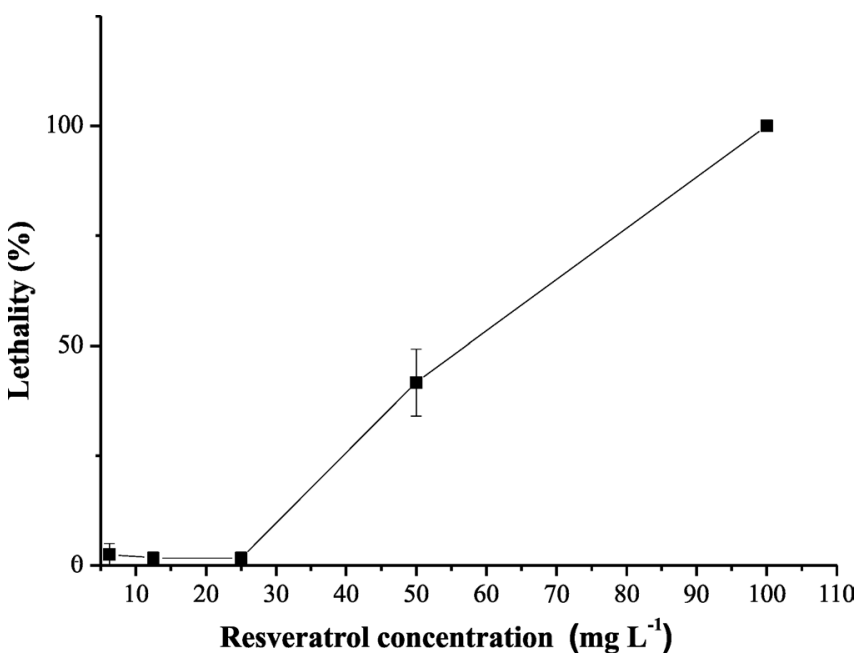

Figure 4: Lethality curve of zebrafish larvae as a function of resveratrol concentrations after $168 \mathrm{~h}$ of exposure. Mean and standard deviation $(n=3)$.

Table 2 - Values of the $\mathrm{LC}_{50}$, confidence intervals, mean, standard deviation and variation coefficient for the short-term chronic ecotoxicity assay of resveratrol in zebrafish $(\mathrm{n}=3)$.

\begin{tabular}{lcc}
\hline Replica & LC50 $\left(\mathrm{mg} \mathrm{L}^{-1}\right)$ & $\begin{array}{c}\text { Confidence limit } \\
\left(\mathrm{mg} \mathrm{L}^{-1}\right)\end{array}$ \\
\hline 1 & 52.7 & $(46.7-59.4)$ \\
2 & 49.7 & $(44.3-55.7)$ \\
3 & 51.7 & $(46-58.2)$ \\
Mean & $\mathbf{5 1 . 4}$ & \\
Standard deviation & 1.5 & \\
Variation coefficient (\%) & 0.03 & \\
\hline
\end{tabular}

At concentrations of 50 and $100 \mathrm{mg} \mathrm{L}^{-1}$ were observed deformities in the organisms and lethality during the assay. The observed deformities were: pericardium oedema, oedema of the yolk sac and a spine deformity showns in figure 5 . Such deformities were observed by several authors who studied the toxicity of drugs and some metals: Akande et al. (2010); Li et al. (2017); Oliveira et al. (2009); Oliveira et al. (2013); Tesolin et al. (2014); Tokunaga et al. (2016). All deformations were statistically different from the controls.

Oedema has been one of the malformations most observed in toxicity studies with Danio rerio (Tesolin et al., 2014). The presence of pericardial oedema is due to cardiac dysfunction, functioning as an indicator of osmotic or metabolic dysfunction, frequently associated with extravasations of the endothelial vessels (Dejana et al., 2009; Hallare et al., 2005; Ali et al., 2014) or it is due to renal dysfunction, since the regulation system depends on renal involvement (Coelho, 2004).

Spine deformations can be linked with the depletion or deregulation of ions such as calcium and phosphorus, or with reduction of myosin, both necessary for the normal development of the organism (Cheng et al., 2000).

The larvae with deformities showed less activity compared to the control larvae. In the study by Suvarchala \& Philip (2016) with insecticide 3,5,6-Trichloro-2-pyridinol (TCP), larvae of Danio rerio presented the same deformities observed in this study, as well as altered swimming behavior. These same effects were observed by Lutte (2015) who studied the metabolism of adenosine in a model of fetal alcohol syndrome in Danio rerio.

In this study, the deformities observed in the Danio rerio exposed to resveratrol were similar in all trials performed, as these deformities were similar to the toxicity tests of drugs, some metals and insecticides.

Crowell et al. (2004) conducted a study in rats to verify the toxicity of resveratrol. At the high dose administration (3000 $\mathrm{mg} / \mathrm{kg} /$ day) adverse effects were observed, such as weight loss and changes in haematological parameters. In another study, with healthy volunteers, a single dose of resveratrol was given at 4 different concentrations: $0.5 ; 1 ; 2.5$ and $5 \mathrm{~g}$. No adverse effects were observed in volunteers (Boocock et al., 2007). According to Gillespie \& Lenz (2012), studies suggest that oral doses of up to $1 \mathrm{~g}$ per day of resveratrol in humans are well tolerated. Gastrointestinal discomfort and diarrhea were
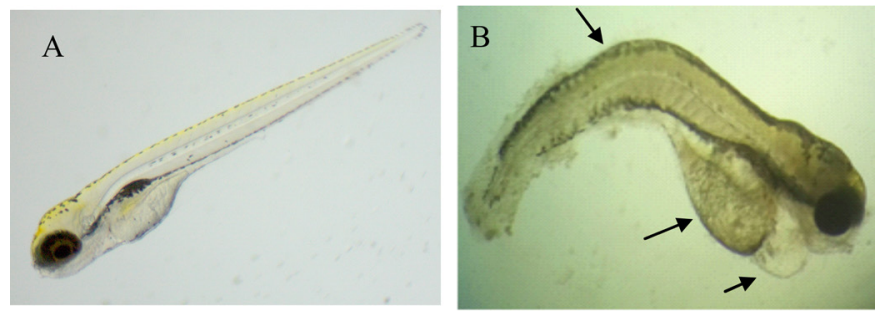

Figure 5: Deformities in zebrafish larvae after exposure to resveratrol during $96 \mathrm{~h}$ : (A) Control in the period of $96 \mathrm{~h}$; (B) Larvae at the concentration of $50 \mathrm{mg} \mathrm{L}-1$ with oedema of pericardium, oedema of yolk sac and spine deformity in the period of $96 \mathrm{~h}$ (black arrows). 
observed with oral administrations of the compound at doses greater than $2.5 \mathrm{~g}$ per day

\section{CONCLUSION}

Resveratrol is largely present in a variety of foods and beverages, and that there is no data in the literature on its concentration in the aquatic environment, the knowledge of its toxicity is highly necessary. This study provided data about resveratrol toxicity in embryolarval stage on Danio rerio fish. The toxic effects of resveratrol in Danio rerio are dependent on its concentration, presenting a toxic effect similar to other compounds found in the literature. Resveratrol may have an effect on aquatic biota, which propose on a necessity toassess the disposal of this compound in water bodies.

\section{ACKNOWLEDGEMENTS}

The author thanks CAPES for the scholarship which enabled the project realization.

\section{REFERENCES}

ABNT (Associação Brasileira de Normas Técnicas). 2007. Ecotoxicologia aquática- Toxicidade crônica de curta duração - Método de ensaio com peixes NBR 15499, Rio de Janeiro RJ.

AKANDE, M.G., ORN, S. \& NORRGREN, L. 2010. Evaluation of the toxic effects of clozapine in zebra fish (Danio rerio) embryos with the fish embryo toxicity test. IJPBR., 1(4): 90-94.

ALI, S., AALDERS, J. \& RICHARDSON, M.K. 2014. Teratological effects of a panel of sixty water-soluble toxicants on zebrafish development. Zebrafish, 11(2): 129-141. http://dx.doi. org/10.1089/zeb.2013.0901

BAI, W., TIAN, W., ZHANG, Z., HE, H., MA, Y., LIU, N. \& CHAI, Z. 2010. Effects of copper nanoparticles on the development of zebrafish embryos. J. Nanosci. Nanotechnol., 10(12): 8670-8676. http://dx.doi.org/10.1166/jnn.2010.2686

BAR-LLAN, O., ALBRECHT, R.M., FAKO, V.E. \& FURGESON, D.Y. 2009. Toxicity assessment of multisized gold and silver nanoparticles in zebrafish embryos. Small, 5(16):1897-910. http://dx.doi.org/10.1002/smll.200801716

BOOCOCK, D.J., FAUST, G.E.S., PATEL, K.R., SCHINAS, A.M., BROWN, V.A., DUCHARME, M.P., BOOTH, T.D., CROWELL, J.A., PERLOFF, M., GESCHER, A.J., STEWARD, W.P. \& BRENNER, D.E. 2007. Phase I dose escalation pharmacokinetic study in healthy volunteers of resveratrol, a potential cancer chemopreventive agente. Cancer Epidemiol. Biomark. Prev., 16(6): 1246-1252. http://dx.doi. org/10.1158/1055-9965.EPI-07-0022

CHENG, S.H., WING, K.W.A., HUNG, S.C. \& SHIU, S.W.R. 2000. Cellular and molecular basis of cadmium-induced deformities in zebrafish embryos. Environ. Toxicol. Chem., 19(12): 3024-3031. http://dx.doi.org/10.1002/etc.5620191223

COELHO, E.B. 2004. Mecanismos de formação de edemas. Medicina Ribeirão Preto, 37(3): 189-198. http://dx.doi.org/10.11606/ issn.2176-7262.v37i3/4p189-198

CROWELL, J.A., KORYTKO, P.J., MORRISEY, R.L., BOOTH, T.D. \& LEVINE, B.S. 2004. Resveratrol-associated renal toxicity. Toxicol. Sci., 82(2): 614-619. http://dx.doi.org/10.1093/ toxsci/kfh 263
DAMASCENO, K.C., MAZIERO, J., KUSCHINSKY, A., MAMEDE, F.C.S., MARTINI, G.A., ROGERO, S.O. \& ROGERO, J.R. 2016. Avaliação ecotoxicológica do Resveratrol em Daphnia similis. In: III Simpósio de Ecotoxicologia, 2016, Rio Claro. Annals... Rio Claro, 2016. p. 104.

DAVE, G. \& XIU, R. 1991. Toxicity of mercure, copper, nickel, lead, and cobalt to embryos and larvae of zebrafish, Brachydanio rerio. Arch. Environ. Contam. Toxicol., 21(1):126-134. http:// dx.doi.org/10.1007/BF01055567

DEJANA, E., TOURNIER-LASSERVE, E. \& WEINSTEIN, B.M. 2009. The control of vascular integrity by endothelial cell junctions: molecular basis and pathological implications. Dev. Cell., 16(2): 209-221. http://dx.doi.org/10.1016/j. devcel.2009.01.004

FERNÁNDEZ-MAR, M.I., MATEOS, R., GARCÍA-PARRILHA, M.C., PUERTAS, B. \& CANTOS-VILLAR, E. 2012. Bioactive compounds in wine: Resveratrol, hydroxytyrosol and melatonin: A review. Food Chem., 130(4): 797-813. http://doi.org/10.1016/j. foodchem.2011.08.023

FUIMAN, L.A. 2002. Special considerations of fish eggs and larval. In: Fuiman, L.A. \& Werner, R.G. (ed), Fishery Science: The unique contributions of early life stage. Oxford: Blacwell Science, pp.1-32.

GILLESPIE, N.D. \& LENZ, T.L. 2012. Resveratrol: Potential benefits on aging and heart disease. Am. J. Lifestyle Med., 6(5): 390-392. http://dx.doi.org/ 10.1177/1559827612448314

GRUNWALD, D.J. \& EISEN, J.S. 2002. Headwater of the zebrafishemergence of a new model vertebrate. Nat. Rev. Genet., 3(9): 717-724. http://dx.doi.org/10.1038/nrg892

GÜLÇIN, I. 2010. Antioxidant properties of resveratrol: A structureactivity insight. Innov. Food Sci. Emerg. Technol., 11(1): 210218. http://dx.doi.org/10.1016/j.ifset.2009.07.002

HALLARE, A.V., SCHIRLING, M., LUCKENBACH, T., KÖHLER, H.R. \& TRIEBSKORN, R. 2005. Combined effects of temperature and cadmium on developmental parameters and biomarker responses in zebrafish (Danio rerio) embryos. J. Therm. Biol., 30(1): 7-17. http://dx.doi.org/10.1016/j. jtherbio.2004.06.002

HAMILTON, M.A., RUSSO, R.C. \& THURSTON, R.V. 1977. Trimmed Spearman-Karber Method for estimating median lethal concentrations in toxicity bioassays. Environ. Sci. Technol., 11(7): 714-719. http://dx.doi.org/10.1021/es60130a004

HILL, A.J., TERAOKA, H., HEIDEMAN, W. \& PETERSON, R.E. 2005. Zebrafish as a model vertebrate for investigating chemical toxicity. Toxicol. Sci., 86(1): 6-19. http://dx.doi.org/10.1093/ toxsci/kfil10

ISO (International Organization for Standardization). 2009. Biological evaluation of medical devices, Part 5, Tests for in vitro cytotoxicity, Switzerland, 10 993-5.

JEANDET, P., DOUILLET-BREUIL, A.C., BESSIS, R., DEBORD, S., SBAGHI, M. \& ADRIAN, M. 2002. Phytoalexins from the Vitaceae: biosynthesis, phytoalexin gene expression in transgenic plants, antifungal activity, and metabolism. J. Agric. Food Chem., 50(10): 2731-2741. http://dx.doi.org/10.1021/jf011429s

JESUS, F.T., OLIVEIRA, R., SILVA, A., CATARINO, A.L., SOARES, A.M., NOGUEIRA, A.J. \& DOMINGUES, I. 2013. Lethal and sub lethal effects of the biocide chlorhexidine on aquatic organisms. Ecotoxicology, 22(9): 1348-1358. http:// dx.doi.org/10.1007/s10646-013-1121-6

JEZIERSKA, B., LUGOWSKA, K. \& WITESKA, M. 2009. The effects of heavy metals on embryonic development of fish (a review). Fish Physiol. Biochem., 35(4): 625-640. http://dx.doi. org/10.1007/s10695-008-9284-4

KIMMEL, C.B., BALLARD, W.W., KIMMEL S.R., ULLMANN, 
B. \& SCHILLING, T.F. 1995. Stages of embryonic development of zebrafish. Dev. Dyn., 203(3): 253-310. http://dx.doi. org/10.1002/aja.1002030302

LEONARD, S.S., XIA, C., JIANG, B.H., STINEFELT, B., KLANDORF, H.; HARRIS, G.K. \& SHI, X. 2003. Resveratrol scavenges reactive oxygen species and effects radical-induced cellular responses. Biochem. Biophys. Res. Commun., 309(4): 1017-1026. http://dx.doi.org/10.1016/j.bbrc.2003.08.105

LI, K., WU, J.Q., JIANG, L.L., SHEN, L.Z., LI, J.Y., HE, Z.H., WEI, P., LV, Z. \& HE, M.F. 2017. Developmental toxicity of 2,4-dichlorophenoxyacetic acid in zebrafish embryos. Chemosphere, 171: 40-48. http://dx.doi.org/10.1016/j. chemosphere.2016.12.032

LUTTE, A.H. 2015. Avaliação do metabolismo de adenosina em um modelo de síndrome alcoólica fetal em zebrafish (Danio rerio). MSc. Dissertation. Pontifícia Universidade Católica do Rio Grande do Sul, Porto Alegre, 81p.

MUKHERJEE, S., DUDLEY, J.I. \& DAS, D.K. 2010. Dosedependency of resveratrol in providing health benefits. Dose Response, 8(4): 478-500. http://dx.doi.org/10.2203/doseresponse.09-015.Mukherjee

MULLER, E.B., LIN, S. \& NISBET, R.M. 2015. Quantitative adverse outcome pathway analysis of hatching in zebrafish with $\mathrm{CuO}$ nanoparticles. Environ. Sci. Technol., 49(19): 1181711824. http://dx.doi.org/10.1021/acs.est.5b01837

OECD (Organization for Economic Co-operation and Development). 2013. Guideline for the testing of chemicals. Fish embryo acute toxicity (FET) test $\mathrm{N}^{\circ} 236$, Paris.

OLIVEIRA, R., DOMINGUES, I., GRISOLIA, C.K. \& SOARES, A.M. 2009. Effects of triclosan on zebrafish early-life stages and adults. Environ. Sci. Pollut. Res. Int., 16(6): 679-688.http:// dx.doi.org/10.1007/s11356-009-0119-3

OLIVEIRA, R., McDONOUGH, S., LADEWIG, J.C.L., SOARES, A.M.V.M., NOGUEIRA, A.J.A. \& DOMINGUES, I. 2013. Effects of oxytetracycline and amoxicillin on development and biomarkers activities of zebrafish (Danio rerio). Environ. Toxicol. Pharmacol., 36(1): 903-912. http://dx.doi.org/10.1016/j. etap.2013.07.019
SUVARCHALA, G. \& PHILIP, G.H. 2016. Toxicity of 3,5,6-trichloro-2-pyridinol tested at multiple stages of zebrafish (Danio rerio) development. Environ. Sci. Pollut. Res. Int., 23(15): 15515-15523. http://dx.doi.org/10.1007/s11356-0166684-3

TESOLIN, G.A.S., MARSON, M.M., JONSSON, C.L., NOGUEIRA, A.J.A., FRANCO, D.A.S., ALMEIDA, S.D.B., MATALLO, M.B. \& MOURA, M.A.M. 2014. Avaliação da toxicidade de herbicidas usados em cana-de-açúcar para o Paulistinha (Danio rerio). Mundo Saúde, 38(1): 86-97. http:// dx.doi.org/10.15343/0104-7809.20143801086097

TOKUNAGA, S., WOODIN, B.R. \& STEGEMAN, J.J. 2016. Plant lignan secoisolariciresinol suppresses pericardial edema caused by dioxin-like compounds in developing zebrafish: Implications for suppression of morphological abnormalities. Food Chem. Toxicol., 96(1): 160-166. http://dx.doi.org/10.1016/j. fct.2016.07.012

VALLVERDÚ-QUERALT, A., BOIX, N., PIQUÉ, E., GÓMEZCATALAN, J., MEDINA-REMON, A., SASOT, G., MERCADER-MARTÍ, M., LLOBET, J.M. \& LAMUELARAVENTOS, R.M. 2015. Identification of phenolic compounds in red wine extract samples and zebrafish embryos by HPLCESI-LTQ-Orbitrap-MS. Food Chem., 181(1): 146-151. http:// dx.doi.org/10.1016/j.foodchem.2015.02.098

VANETTEN, H.D., MANSFIELD, J.W., BAILEY, J.A. \& FARMER, E.E. 1994. Two classes of plant antibiotics: phytoalexins versus "phytoanticipins". Plant Cell., 6(9): 1191-1192. http://dx.doi. org/10.1105/tpc.6.9.1191

VUONG, T.V., FRANCO, C. \& ZHANG, W. 2014. Treatment strategies for high resveratrol induction in Vinis vinifera $L$. cell suspension culture. Biotechnol. Rep. (Amst)., 1(2): 15-21. https://doi.org/10.1016/j.btre.2014.04.002

ZAGATTO, P.A. \& BERTOLETTI, E. 2006. Ecotoxicologia aquática - Princípios e Aplicações. Rima, São Carlos, SP. 478p. 